\title{
Leveraging Intellectual Capital in developing countries: Evidence from Kenva
}

\section{INTRODUCTION}

Intellectual capital (IC) performance is strongly related with the resources available (Verona, 1999, Wernerfelt, 1984). At the same time, IC performance is often the result of individual activity, which questions the extent of the benefits of grouping people in an organization, especially in the presence of a context characterized by multiple communities (Bounfour and Edvinsson, 2005). This issue is particularly crucial in developing countries, where tensions arise between strong ties to traditions and the eagerness to foster innovation. Therefore, this paper aims to better understand how diverse organization's resources in developing countries influence IC performance, in particular by looking at a highly individualistic form of IC performance, namely art creation. It then explores the impact of community aspects on IC performance in relation to the other organization's resources.

An in-depth understanding of organization' resources in relation to IC performance is a crucial issue for developing countries (Andreeva and Garanina, 2016). The latter is characterized by high potential for growth: for instance, the World Bank shows that developing countries' economies grew at 4.3 percent in 2015 and are projected to grow 4.8 percent in 2016, whereas developed economies show a 2.4 percent growth in 2015, which is projected at 2.9 percent in 2016 (World Bank, 2016a). In particular, despite its large heterogeneity, Africa has a large, still unfulfilled, potentiality (AfDB et al., 2016). Developing countries possess a strong connection to their traditions (Abraham, 2015, Iliffe, 2015). This feature could represent a competitive advantage for them, if appropriately valorized. At the same time, it could be a limitation since it could lead to increased rivalry among different communities, discouraging collaboration and sharing of information. Therefore, besides its economic relevance, the study of IC in developing countries is further theoretically motivated by the presence of the peculiar role that the community aspect plays, which needs to be taken into account in understanding the impact of the different resources on IC performance. 
In this study, IC performance, the result of organization's resources, is measured as art creation. Art represents one of the most complex results of IC performance (Sgourev, 2013). It is often performed at individual level, but it requires a broad audience in order to be valorized (Collingwood, 1938, Beardsley, 1965, Sgourev, 2013). Moreover, it is characterized, on the one hand, by the expectation to disrupt the existing products, and on the other hand it is often strongly connected to traditional knowledge and culture. The latter plays a crucial role in art creation, and in the way the related work is organized. This aspect is extremely evident in countries with a strong traditional legacy, where divisions due to traditional heritage still represent a major source of conflict (Iliffe, 2015). Furthermore, art represents one of the most important form of IC performance in developing countries, but is still poorly valorized (Sieber and Walker, 1987). So far, there has been a lack of evidence on the functioning of organizations grouping together artists, especially in a context characterized by high rivalry and traditional legacy. Therefore, it is possible to observe that art creation provides an ideal setting to investigate IC performance.

Overall, a gap exists in the understanding of how organization's resources contribute to IC performance in developing countries. Resting on the resource-based theory, this paper aims to investigate (1) how diverse organization's resources impact IC performance in developing countries, and (2) the impact of the community aspect in relation to the other organization's knowledge resources. Specifically, the paper considers the following resources, i.e. human, social and organizational, to investigate the two impacts mentioned above.

To address these research questions, this article performs an in-depth case study on an art school program, named in this work "WE" for anonymity, in Malindi (Kenya). This organization had been initially launched by an Italian artist as part of a broader project with the scope to promote the local culture. In particular, it aims to train local artists and to facilitate the international exposure of their work. This setting provides an ideal field of enquiry since it is characterized by a high level of 
informality, the presence of strong cultural roots, and communication difficulties that further exacerbate the tensions among organizations' members in the work creation process.

The empirical findings document that multiple organization's resources, i.e., human, social and organizational, impact IC performance. Social and organizational resources have the largest positive effect, meaning that grouping together people is beneficial for the final outcome. Furthermore, the community aspect has an incremental positive role to social capital. Thus, it is possible to infer its role in facilitating knowledge interactions and creation of networks, which overall positively influence IC performance.

This research represents an attempt to understand organization's resources in IC performance in developing countries. Moreover, it gathers insights on the influence of community aspects into relational resources (i.e. social and organizational), further developing IC theory concerning different institutional and socio-cultural contexts.

The remainder of this paper is organized as follows. Section 2 presents the conceptual framework based on the resource based-view. Section 3 describes the research design used to investigate the research questions. Section 4 presents the findings. The final Section shows the evidence gathered and it draws implications for future programs aiming to develop IC in developing countries, primarily in Africa.

\section{CONCEPTUAL FRAMEWORK}

IC performance is often equated as the result of unique and disruptive knowledge (Nonaka and Takeuchi, 1995). In fact, IC can be defined as the knowledge resources which create value (Ashton, 2005, Lev, 2000, Meritum, 2002). From an organizational perspective, past literature considers IC as the outcome of the combination of organization's resources (Andreeva and Garanina, 2016, Nahapiet and Ghoshal, 1998, Youndt et al., 2004, Wernerfelt, 1984). Subramaniam and Youndt (2005) identify 
human-based, social-based and organizational-based as the three main sources of organization's resources.

Human resources can be defined as the set of knowledge, skills and abilities at individual level developed and deployed in order to be productive, effective and innovative (Schultz, 1961). Social resources are considered as the knowledge which arises through interactions among individuals and groups of people (Nahapiet and Ghoshal, 1998). Finally, organizational resources can be defined as the overall institutionalized knowledge and codified experience which are used and shared through systems and processes (Youndt et al., 2004). Each form of resources is grounded at a different aggregation level, such as individual, network and organization.

Moreover, it is necessary to question the relevance and the relationships among resources when it comes to IC forms of performance in contexts characterized by informality and community aspects. The latter are defined as values, spirits and principles apt to bond human capital (North and Kares, 2012, Edvinsson et al., 2005). These contexts may encapsulate potential levels of rivalry and reluctance to new forms of aggregation. Organizational resources appear as the result of repeated and cooperative activities (Nelson and Winter, 1982), which are later handed down either verbally or through formal documents and processes. Differently, social capital is not bound within prescribed parameters, but is characterized by high flexibility in knowledge and information sharing, and can operate as a leverage to facilitate the development of human and organizational resources (Kostova and Roth, 2003). Therefore, it is necessary to further investigate the relationships between relational (i.e., social and organizational) resources and community aspects, in order to better understand the overall process of IC performance.

Prior literature highlights the relevance of human resources in describing IC outcomes (Williams, 2001). Our focus is to understand whether the value creation related to IC performance represents the result of individual activity or if it also benefits from social and organizational interactions. Our measure of IC performance places an emphasis both on the outcome, i.e., art, and on 
the improvements in terms of value creation of the entity analyzed. Moreover, the high informal organizational structure of the entity analyzed as well as peculiar characteristics of the industry investigated do not allow to use more direct measures of value creation, e.g., VAIC (Barathi Kamath, 2007; Williams, 2001).

The extent to which people within an organization are willing to share ideas and valuable information is strictly related to the so-called public good dilemma, where every individual can make an individual profit by being selfish (Cabrera and Cabrera, 2002, Allison et al., 1996). This attitude is potentially detrimental to the group's best long-term interests, nullifying the immediate benefits obtained. In the case analyzed in this study, artists could simply decide to continue working on an individual basis, with scant collaboration, and with little exploitation or immediate depletion of the resources available within the organization.

In fact, art creation shares strong similarities with both radical and incremental innovations, since on the one hand it depicts a situation in which a completely new product is conceived and realized, and on the other hand, it can rely on existing/traditional knowledge. Despite the presence of disruptive elements in art creation, the latter is still the result of a combination of a multitude of knowledge resources. Moreover, art creation is often performed at local and individual level with poor results in terms of external exposure and valorization. It is also characterized by the fact that from the inception or first inspiration of the artist, to the final art creation, subsists a process which in its development, may be guided and shared until its completion (Beardsley, 1965). Therefore, it is necessary to question the possible benefits that art creation could obtain by an aggregation of individuals, and to what extent it draws upon human, social and organizational resources.

The aforementioned theoretical framework finds its natural ground in the study of IC in developing countries. These countries are characterized by a strong connection to their traditional values (Bontis, 2004, Seleim and Bontis, 2013). The traditional division in small communities could 
lead to possible tensions among individuals of different regions as well as reluctance to share information. At the same time, traditional knowledge can represent an underdeveloped source of competitive advantage, which could be used to foster IC performance. Moreover, developing countries may not manage knowledge and IC as developed countries do (Andreeva and Garanina, 2016, Adekunle Suraj and Bontis, 2012). Developing countries have a lower degree of formality, leading to a potential central role of individual knowledge and so, IC could still strongly be embedded in the traditional system. Finally, organizations operating in developing countries often lack financial resources. The latter is usually considered highly important to create connectivity among individuals, actors and activities (Marzo and Scarpino, 2016). These characteristics could affect the way knowledge resources are used. Despite the growing role that these countries are playing in the global economy and their potential for growth, literature on IC in developing countries is still scant. Past research mainly focuses on the reporting of IC activities in developing countries, rather than on the use of knowledge resources (Abeysekera and Guthrie, 2004, Abeysekera and Guthrie, 2005, Chen et al., 2004).

Overall, the aim of this study is to contribute to the current debate on the relationship between organization's resources and IC performance, investigating art creation, in developing countries. Thus, this article attempts to address the following research questions:

RQ1. How do organization's resources contribute to improve IC performance in developing countries?

RQ2. What is the moderating effect of community and relational (i.e. social and organizational) resources on IC performance?

\section{RESEARCH DESIGN}


This section presents the methods adopted to conduct this study and the related setting. It then provides both theoretical and empirical elements to justify the methodological choices. Finally, it discusses the procedures followed to analyzed the data collected.

\subsection{The case study: the WE project}

To address the research questions, this paper carries out an in-depth case study. The latter is particularly suited for studying IC performance, considering the uniqueness of each process (Sgourev, 2013, Hargadon and Douglas, 2001). The case-study approach is also appropriate considering its inclination to explore complex questions, disentangling them with the use of a wide-set of data and information (Yin, 1994). The analysis includes survey data, both semi-structured and structured interviews carried out formally and informally, observations and a wide collection of documentation (e.g. newspapers articles, pictures, reports, web information and other multimedia). The data triangulation allows us to validate the empirical results and to interpret through a performative approach (Marzo and Scarpino, 2016, Mouritsen, 2006). Moreover, the complexity of the cultural, social and economic settings which characterize art creation in Kenya further motivates this methodological approach (Vale et al., 2016). Table 1 shows the data sources used.

\section{[PLEASE, INSERT TABLE 1 HERE]}

The case-study "WE" consists of an art school regrouping Kenyan artists, with different levels of experience, and directed by an experienced artist. The latter is originally from Italy, but he is strictly connected to the African cultural and artistic environment. For instance, he has also represented Kenya 
at the Venice Biennale, an international and important visual art exhibition ${ }^{1}$. The artist/project founder's Facebook biography clearly highlights the goal of the activities performed in Africa:

"Why don't we turn our head to this forgotten world placed under Equator? Why don't we try to help them to make concrete the huge richness of their land and their souls? Not as missionaries, but as smart and sincere managers, ready to give and receive." 2

"WE" has been formally recognized by the Kenyan Ministry of Sports, Culture and the Arts in November 2014. It is based in Malindi (Kenya) and it represents one of the first attempts to gather together artists from different villages, to produce and sell art works worldwide. The art school is part of a broader project which aims to promote both the local culture, for instance with the opening of a museum, and to increase the tourist attractiveness, by developing high quality facilities. At "WE", artists are further trained and perform their work, usually under the supervision of a more experienced artist.

Kenya represents an ideal setting to carry out the research on developing countries. In terms of economic growth, it has performed well in the past decade (World Bank, 2016a). A growing number of modern services are delivered, primarily financial intermediation and mobile communication, leading to demand for services different from trade, in turn leaving room for the valorization of IC (World Bank, 2016b).

\subsection{Data collection}

The analysis relies on a rich set of data gathered over the period 2015-2016. First, questionnaire surveys were administered in autumn 2016 to the participants of the project "WE". Respondents were assured that the answers were used only for research purposes and at aggregate level. Initially, the

\footnotetext{
${ }^{1}$ http://universes-in-universe.de/car/venezia/bien50/ken/e-tanzini.htm

${ }^{2}$ Facebook page of the artist/project Founder.
} 
preliminary questionnaire was piloted to eight different persons ${ }^{3}$ to ensure its understandability and length. The pilot tests lasted between 11 to 45 minutes and they prompted modifications of some questions. After the first period of piloting, the questionnaires were administered in locu, ensuring that all the addressed people responded. The mean survey duration was less than 24 minutes, ranging between a minimum of 15 to a maximum of 30 minutes $^{4}$. The internal consistency of the questions was assessed through Cronbach's alpha; the test results with an alpha mean value of 0.8748 indicating good consistency (Tavakol and Dennick, 2011, DeVellis, 2016, Nunnally et al., 1967). Cronbach's alpha of all scales was greater than 0.8635 , and when deleting any of the items included in our questionnaire the overall reliability did not change/improve much, suggesting a good-fit of items; hence all the items were retained.

The questionnaire consists of a total of 48 questions divided in the following seven sections: respondents' profile, creativity issues, organizational issues, cultural/artistic issues, knowledge sharing process, community aspects and personal thoughts of knowledge sharing. The survey method provides a wider understanding of the underlying characters of the phenomena under investigation and is particularly suited for the IC studies (Andreeva and Garanina, 2016, St-Pierre and Audet, 2011). The questionnaire takes a neutral standpoint without including a specific section on the country level dimension. Indeed, the survey design adopted maximizes the "fitness for use" (Groves et al., 2011) and facilitates replication and relevance for other studies. Also, from a theoretical perspective, we are interested in the relationship between organizations' resources and IC performance and not in the specific local characteristics of the context analyzed. Hence, we adopt a neutral approach to design our

\footnotetext{
${ }^{3}$ The pilot tests were conducted by: two Accounting Professors, a Post-doc research fellow in statistical sciences, a Ph.D. student in Finance, a Ph. D. student in Management accounting and intellectual capital, a high-school student, an Architect and University student in Art and Archeology and a post-graduate student in Art.

${ }^{4}$ In literature it is suggested that the respondents' attention reduces following the first 30 minutes (Perecman and Curran, 2006). Hence, we consider the quality of the responses as satisfactory.
} 
survey questionnaire. See Appendix 1 for the full questionnaire and paragraph 3.3 for the variables, measurements and operationalization.

Secondly, 12 interviews ( 8 semi-structured interviews and 4 structured) were conducted with the different members of this organization and its stakeholders (Table 2). It was followed the general interview guide approach (Patton, 2002: 342) reported in Appendix 2.

[PLESE, INSERT TABLE 2 HERE]

Interviews lasted on average about 26 minutes, ranging from a minimum of 8 minutes to a maximum of 90 minutes. They have been recorded, transcribed and translated by the authors if performed in a language other than English. The translated interviews were then sent to the interviewees asking to check for any possible misunderstanding or inconsistency. The interviews took the form of face-to-face conversations, telephone or Skype interviews and completion of written questionnaires. The twelve interviews are coded with a code from "INT1" to "INT12". All the interviewees were almost asked identical questions even though the structure and composition of the interviews were adapted according to the respondent. Diverse interviewees may have diverse perceptions on the IC performance and may provide important insights. Also, the same subjects have been interviewed more than once to assess the reliability over time of the responses. The results reported are integrated with extracts from interviews, introducing a narrative perspective (Corbetta, 2003).

Thirdly, this study combines the use of participant observations to gather further data and to allow the researchers a full immersion in the case-study. This method is particularly important within the interpretative paradigm, prompting a social awareness from the "participants" standpoint through 
taking part in their lives. This can actually only be realized through continuous interaction between the subjects studied and the researcher (Corbetta, 2003).

In detail, by visiting the laboratories and warehouses of the artist/project founder in Italy, the researchers were able to assess the participants' subjective reporting in the interviews. The researchers contextualized more accurately in this sense, the narrative interchange occurring, and the physical, social and cultural contexts in which the participant lives for a great part of the time (Musante and DeWalt, 2010).

Fourthly, internal material directly provided by the organization is also used, such as the Statute of the organization, emails and other internal documents discussing work organization. Finally, additional data concerning this project on media were gathered, i.e., press articles, blogs, and various social media (Facebook, Instagram, Twitter, and Youtube). Press articles were collected through the software Factiva looking for relevant keywords to the field of enquiry by looking at press articles in English, French and Italian over the last ten years. Forty-six articles were retained and analyzed.

\subsection{Data analysis and variable definition}

This paper adopts a mix methods approach to analyze the data gathered. First, it performs a quantitative analysis of the questionnaire survey. Past studies demonstrate the reliability of this technique in order to investigate the use of IC at firm level (Tsai, 2002, Handzic et al., 2016). It then complements the results obtained from the analysis of the questionnaire survey with the interviews performed, as well as with observations and internal and external documents. Contextual information has been useful to further corroborate the results. The main advantage of this methodological approach is the possibility to triangulate the different findings and thereby validate them.

The fifty survey questionnaires obtained were analyzed according to the following procedure. First, the different responses were aggregated in order to identify the underlying phenomenon 
characterizing organization's resources and IC performance. To this end, a Factor Analysis was performed. This technique presents the advantage of uncovering the main underlying dimensions and reducing the data to reach a more parsimonious comprehension of the determined variables, by setting the number and nature of components necessary to consider the patterns of observed correlations (Hayton et al., 2004). The factor analysis, indeed, is particularly worthy for scale development, which is the case for this study, and where there is scant theoretical basis to identify a preconceived number of components (Hurley et al., 1997). To decide the number of factors to retain, a parallel analysis was performed, which suggest to hold five components. However, cautiously and consistent with prior literature on IC, only the first four common factors were retained in the analysis (Hayton et al., 2004). Also retaining a limited number of factors does not reduce the interpretation of the information provided $^{5}$ (see the paragraphs on the variables measurements for a more exhaustive definition of the four components).

Once determined, the proxy to measure the main sources of IC, the following stage of the analysis used regression analysis.

\section{Variables measurements}

To determine the dependent variable (IC Performance) in the factor analysis, the three main questions regarding the creativity issues are analyzed, i.e., CREATIVE, CREATE and ART_TR.

The independent variables were extracted from the factor analysis, including all the questions except those regarding the respondents' profile. The results of the factor analysis highlight the main common factors recognized amongst organization's resources, namely human, social, and

\footnotetext{
${ }^{5}$ The cumulative amount of variance explained account for the 0.68 . The decision was based considering also eigenvalues higher than 0.3 and Cattell's (1966) scree test, identifying a "cliff" after the fourth component.
} 
organizational. In detail, the HUMAN variable is mainly made up of questions on the individual perceptions of creativity issues, the cultural background of the individual and the time he/she spends working and creating. The SOCIAL component includes questions which best represent the individual interaction with other individuals and the role and relations with other people. For instance, this variable comprises the willingness to listen to other people or the way the individual faces and solves problems and the willingness to share knowledge with others. A third component depicts the ORGANIZATIONAL resources. This variable chiefly embodies the institutionalized practices and procedures resulting in codified structures and knowledge. It is indeed made up of questions on whether the working environment supports the process of knowledge sharing or whether the tools and spaces in the working environment facilitate the information transfer among workers. It also includes the respondent's attitude towards organizing and writing down ideas or projects as well as the attitude towards performing the work individually or in a group as part of an organization. Finally, component four designates the COMMUNITY system of beliefs. As a matter of fact, it evokes the reciprocal feeling amongst colleagues such as their perceptions of the judgement of their work by others, the degree of knowledge amongst colleagues and if they feel encouraged by others in pursuing their work. It also relates to the perceptions of the relation between creativity and community aspects, e.g. if creativity is a characteristic only of eminent people, or if it can be taught, assessed and developed in schools.

The study then explores the interaction between the COMMUNITY and SOCIAL variables to verify the community role in exacerbating or moderating the social effect on the performance of intellectual capital. A similar relation investigates the interaction between COMMUNITY and ORGANIZATIONAL effect on the dependent variable. 
The analysis considers several variables as controls. In detail, it includes the respondent's AGE, SEX and EDUCATION. Additionally, we asked about the GROUP of the population to which the respondent belongs and the primary type of art performed (ARTTYPE).

Table 3 summarizes the description of the variables used in this study.

[PLEASE, INSERT TABLE 3 HERE]

\title{
The models
}

Once the different elements have been aggregated, the relationships with the variables identified have been analyzed through OLS regression with robust standard errors clustered at individual level. Model 1a represents the baseline model investigating the relationship between the three capital resources (HUMAN, SOCIAL and ORGANIZATIONAL) and the intellectual capital performance (IC_Performance). Model $1 \mathrm{~b}$ adds the control variables regarding the respondents' profile. Finally, Model 2 introduces the community aspect (COMMUNITY) and two interaction terms with the COMMUNITY independent variables, i.e. COMMUNITY*SOCIAL and COMMUNITY*ORGANIZATIONAL.

\author{
Model la \\ IC_Performance $=\beta_{0}+\beta_{1} H U M A N+\beta_{2}$ SOCIAL $+\beta_{3}$ ORGANIZATIONAL $+\varepsilon_{i t}$
}

Model $1 b$

IC_Performance $=\beta_{0}+\beta_{1} H U M A N+\beta_{2}$ SOCIAL $+\beta_{3}$ ORGANIZATIONAL $+\beta_{5} A G E+\beta_{6} S E X+$ $\beta_{7} E D U C A T I O N+\beta_{8} A R T T Y P E+\beta_{9} G R O U P+\varepsilon_{i t}$ 
Model 2

IC_Performance $=\beta_{0}+\beta_{1} H U M A N+\beta_{2}$ SOCIAL $+\beta_{3}$ ORGANIZATIONAL $+\beta_{4}$ COMMUNITY $\beta_{5}$ COMMUNITY*SOCIAL $+\beta_{6}$ COMMUNITY*ORGANIZATIONAL $+\beta_{7} A G E+\beta_{8} S E X+$ $\beta_{9} E D U C A T I O N+\beta_{10} A R T T Y P E+\beta_{11} G R O U P+\varepsilon_{i t}$

The variables included in the models are explained above and summarized in Table 3.

Interviews and internal and external documents were then analyzed as follows. The material collected was first reviewed in order to identify the macro-themes related to the field of enquiry. Afterwards, an exhaustive coding form to re-examine the material collected was performed, focusing on the organization's knowledge resources, and the art creation. The primary scope of this further exploration is to support and corroborate the findings from the regression analysis. All the evidence gathered from the data is the result of the joint discussion of all researchers involved in this study in order to ensure the validity of the findings reported.

\section{FINDINGS}

This section presents the results gathered from the data analysis. It first provides evidence of the impact of organization's resources in leveraging IC. It then presents how knowledge resources are related to the community aspects. In both cases, the results from the analysis of the survey questionnaires are initially presented. These findings are complemented and clarified by the evidence obtained from analysis of the interviews and of the other documentation.

\subsection{Organization's knowledge resources: a multidimensional situation}


The presence of multiple resources within the organization is confirmed by the analysis conducted. Table 4 Column 1 reports the results with the baseline model. Human, social and organizational resources are positively and significantly related to IC performance. Among the different variables, social and organizational resources have the largest effect over IC performance. These results are robust to the inclusion of several control variables concerning the socio-demographic characteristics of the respondents (Table 4 Column 2).

\section{[PLEASE, INSERT TABLE 4 HERE]}

The role of human, social, and organizational resources in influencing IC performance also emerges from the analysis of the other material collected. The human skills and knowledge applied to art are particularly strong in the Kenyan context, thanks also to a long tradition of art creation. One collaborator of the project says:

"As I said, there are men with diverse roles but with common denominators: love and sensibility; if these positive men, ready to give to the other without asking for something back communicate, it triggers a process of social growth". [INT2]

Social capital is considered as one of the key characteristics of the "WE" project, to the level that it is externally perceived and appreciated. A buyer, who repeatedly visited the organization in Kenya, affirmed:

"The organization "WE", can be considered as a schools of Art, whatever art form it may be, serve to teach technique, to share ideas with peers and ultimately to unlock potential”. [INT10]

The importance of the organizational aspect, and its value added on IC performance, is strongly emphasized by the numerous actors involved in the project, as well as in the definition of the 
workspace. The young craftsmen are expected to constantly present their creations to the Project Founder and to the rest of the organization. As one collaborator said:

"[The young craftsmen begin to attend] the art organizations laboratories. Paintings, sculpture, photography, texture and leather laboratories. Laboratories where you can teach, learn, exchange ideas and vision, invent...laboratories where they can consult present and past testimonies in the form of art, books, photographs, movies, music and food. Thanks to the dedicated areas: museum, library, game room and canteen" [INT2].

Overall, the empirical findings document that multiple organization's resources, i.e., human, social and organizational, impact IC performance, with a different degree of impact.

\subsection{Unfolding the community aspect to leverage IC}

The results regarding the impact of community aspects on IC performance are reported in Table 4 Column (3). The focus is on the interaction between community and relational resources (i.e., social and organizational). First, the relation between community aspects and social capital is significant and positive, showing the incremental effect on IC performance. Secondly, the relation between community and organization capital is not significant, meaning that their interaction has no impact on IC performance. The explanation power of the model is satisfactory (R-Squared $85.40 \%$ ).

The community represents a fundamental element of the project and is embedded in its creation and functioning. The artist/project manager affirms that the choice to initially locate the organization in Malindi was motivated "by the presence of numerous races and religions. It is one of the oldest towns on Kenyan Coast." [INT1 $]^{6}$

Moreover, the willingness to share information and to interact is part of the community values. Illustrative is a quote of Employee and former Art-student within the project:

\footnotetext{
${ }^{6} \mathrm{http}: / /$ archivio.panorama.it/archivio/La-mia-Africa-salvata-dagli-artisti
} 
"We do like sharing our knowledge because we believe in the proverb which says that one stone cannot support a cooking pot. African artists like collaborating through sharing ideas." [INT8]

At the same time, there is still distrust towards the organizational aggregation among local communities "Creativity has never been transcripted. [...] Local people are really good artists, but they lack of organizations. They often have short-term goals." [INT 1]. Even in their daily organizations, one of the major difficulties is the definition of routines or systematization of practices.

\section{DISCUSSION AND CONCLUSION}

The first goal of this study is to better understand how organization's resources could contribute to improve IC performance in developing countries. The latter presents intrinsic characteristics which may influence the relationship between organization's resources and IC performance. Through the use of quantitative and qualitative approaches, the study triangulates the results from survey responses, interviews, direct observations and the use of other documents providing both theoretical and practical contributions.

The findings show that human, social and organizational resources influence IC performance. It is therefore remarkable that the different levels of aggregation play a role in the final outcome. In particular, the largest effects are attributed to the social and organizational resources. The aggregation of people is beneficial to IC performance, overcoming individual differences. Therefore, the results are consistent across different degrees of aggregation; i.e., network and organization level. This result is consistent with the idea that organizations group together people in an attempt at collective achievement to increase the likelihood of higher IC performance (Allen, 1977). The possibility of 
social interaction as well as the codification of practices and routines, leads individuals to gain further access to new information and knowledge.

Therefore, an increased intensification of aggregation in work organizations could represent an interesting and valid path to undertake towards sustainable and positive growth. The presence of an organized workspace, adequate tools, and codified practice are extremely beneficial in supporting the improvement of IC resources' performance in developing countries. This type of initiative could also be initially started by non-local people, as long as the socio-cultural context is well-understood, as in the case under analysis. The evidence gathered is particularly significant, especially considering the setting analyzed, art creation, which has a strong individual component in its process creation.

Secondly, this study addresses the question of the impact of community aspects on IC performance. In particular, the focus is on the interaction with the relational capital (i.e., social and organizational). The results document that the community aspects encourage and facilitate IC performance, allowing for integration amongst individuals and their interactions and networks. Therefore, these findings contradict the view that community aspects may represent a major source of rivalry, which would have discouraged or impeded knowledge sharing. In this light, it is possible to infer its role in facilitating knowledge interactions and creation of networks, which overall positively influence IC performance.

At the same time, it emerges that the community aspects have no incremental effect on organizational capital. This fact can be explained by the high degree of informality that has characterized developing countries for a longtime. The evidence gathered shows that informal coordination is strongly embedded in individuals' routines. Nevertheless, community aspects do not hamper the added value of formal mechanisms characterizing the organizational capital.

The contributions of this study are manifold. First, this paper provides a better understanding on how organization's resources lead to IC performance in a developing country, namely Kenya. By 
looking to a setting characterized by a high degree of complexity, these findings address the call for more empirical research on the link between resources and IC performance (Subramaniam and Youndt, 2005). Moreover, differently from Andreeva and Garanina (2016), this study shows the positive impact of relational capital in facilitating interactions among individuals, with a positive impact on IC performance. The presence of discrepancies shows the relevance of regional differences among developing countries concerning relational elements.

Secondly, these findings contribute to the understanding of community aspects in IC performance. This aspect is further emphasized by its positive interaction with social resources, and its lack of relation to organizational aspects. These findings help to unfold the contribution of community aspects, especially in developing countries, where community values, spirit and principles play a key role in society nowadays.

Thirdly, this study addresses the call for more research on programs implemented at organizational level to leverage IC. It provides empirical evidence on how a group of artists, originally from different Kenyan communities, collaborate and jointly work together in an organized setting. The networks and interactions among individuals as well as the codification of experience and practices have a beneficial result on IC performance, and so, foster the economy. Moreover, this study also sheds lights on one of the main challenges of IC performance, namely the valorization of traditional knowledge, in this case art creation, and making it concrete and sustainable in less developed areas of the world.

Like all studies, this research is not without its limitations. First, it is based on a single organization in a particular setting. We caution the reader to generalize our results due to peculiarities of our setting. Future studies could examine the possible influence of local peculiarities due to the legal, social, cultural and economic context, for instance by performing a comparative study. The transformation from "mono-artist (or mono-producer)" to "active and group artists" widens the appeal 
and is key to value co-creation. Value derives from the interactions of personal experiences, experiments, emotions, symbolic and non-utilitarian aspects of creation (Payne et al., 2008; Edvardsson et al., 2011). Given the relevance of the joint and collaborative process in generating IC in developing countries, future research could adopt the co-creation theoretical model. The latter would help to further uncover the material and symbolic aspects of social interactions which shape IC performance. Secondly, the measures of resources adopted may have been influenced by the early stage which characterized the organization investigated and the relevance of the informal interactions among coworkers. It could be interesting to complement and compare our results by looking at how organizations externally report their IC performance. Ultimately, IC performance is a nuanced and multifaceted construct. Because of the inherent difficulties in measuring IC performance, we use a measure based on multiple elements, i.e., art creations, creativity and art training. Despite the use of prior literature (Williams, 2001; Chen Goh, 2005; Barathi Kamath, 2007) and the personal knowledge of the researchers involved of the setting, we acknowledge that with this measure we probably capture most of the aspects concerning IC performance of the case study analyzed. 


\section{References}

ABEYSEKERA, I. \& GUTHRIE, J. 2004. Human capital reporting in a developing nation. The British Accounting Review, 36, 251-268.

ABEYSEKERA, I. \& GUTHRIE, J. 2005. An empirical investigation of annual reporting trends of intellectual capital in Sri Lanka. Critical Perspectives on accounting, 16, 151-163.

ABRAHAM, W. E. 2015. The mind of Africa, Sub-Saharan Publishers.

ADEKUNLE SURAJ, O. \& BONTIS, N. 2012. Managing intellectual capital in Nigerian telecommunications companies. Journal of Intellectual Capital, 13, 262-282.

AFDB, OECD \& UNDP 2016. African Economic Outlook 2016. Paris: AfDB, OECD \& UNDP.

ALLEN, T. J. 1977. Managing the flow of technology: technology transfer and the dissemination of technological information within the $R \& D$ organization, Cambridge, The MIT Press.

ALLISON, S. T., BEGGAN, J. K. \& MIDGLEY, E. H. 1996. The quest for" similar instances" and" simultaneous possibilities": Metaphors in social dilemma research. Journal of Personality and Social Psychology, 71, 479.

ANDREEVA, T. \& GARANINA, T. 2016. Do all elements of intellectual capital matter for organizational performance? Evidence from Russian context. Journal of Intellectual Capital, $17,397-412$.

ASHTON, R. H. 2005. Intellectual capital and value creation: a review. Journal of accounting literature, 24, 53.

BARATHI KAMATH, G. 2007. The intellectual capital performance of the Indian banking sector. Journal of Intellectual Capital, 8(1), 96-123.

BEARDSLEY, M. C. 1965. On the creation of art. The Journal of Aesthetics and Art Criticism, 23, 291-304.

BOUNFOUR, A. \& EDVINSSON, L. 2005. Intellectual capital for communities. Oxford: Butterworth-Heinemann. Elsevier.

BONTIS, N. 2004. National intellectual capital index: a United Nations initiative for the Arab region. Journal of Intellectual capital, 5, 13-39.

CABRERA, A. \& CABRERA, E. F. 2002. Knowledge-sharing dilemmas. Organization studies, 23, 687-710.

CATTELL, R. B. 1966. The scree test for the number of factors. Multivariate behavioral research, 1, 245-276.

CHEN GOH, P. 2005. Intellectual capital performance of commercial banks in Malaysia. Journal of intellectual capital, 6(3), 385-396.

CHEN, J., ZHU, Z. \& YUAN XIE, H. 2004. Measuring intellectual capital: a new model and empirical study. Journal of Intellectual capital, 5, 195-212.

COLLINGWOOD, R. 1938. The Principles of Art. London: Oxford University Press.

CORBETTA, P. 2003. Social research: Theory, methods and techniques, Sage.

DEVELLIS, R. F. 2016. Scale development: Theory and applications, Thousand Okas, Sage publications. 
EDVARDSSON, B., TRONVOLL, B. \& GRUBER, T. 2011. Expanding understanding of service exchange and value co-creation: a social construction approach. Journal of the Academy of Marketing Science 39 (2):327-339.

EDVINSSON, L., HOFMAN-BANG, P. \& JACOBSEN, K. 2005. Intellectual capital in waiting-a strategic IC challenge. Handbook of Business Strategy, 6, 133-140.

GROVES, R. M., FOWLER JR, F. J., COUPER, M. P., LEPKOWSKI, J. M., SINGER, E. \& TOURANGEAU, R. 2011. Survey methodology. Vol. 561: John Wiley \& Sons.

HANDZIC, M., DURMIC, N., KRALJIC, A., KRALJIC, T. \& CHASE, R. 2016. An empirical investigation of the relationship between intellectual capital and project success. Journal of Intellectual Capital, 17.

HARGADON, A. B. \& DOUGLAS, Y. 2001. When innovations meet institutions: Edison and the design of the electric light. Administrative science quarterly, 46, 476-501.

HAYTON, J. C., ALLEN, D. G. \& SCARPELLO, V. 2004. Factor retention decisions in exploratory factor analysis: A tutorial on parallel analysis. Organizational research methods, 7, 191-205.

HURLEY, A. E., SCANDURA, T. A., SCHRIESHEIM, C. A., BRANNICK, M. T., SEERS, A., VANDENBERG, R. J. \& WILLIAMS, L. J. 1997. Exploratory and confirmatory factor analysis: Guidelines, issues, and alternatives. Journal of organizational behavior, 18, 667-683.

ILIFFE, J. 2015. Emergence of African Capitalism, Springer.

KOSTOVA, T. \& ROTH, K. 2003. Social capital in multinational corporations and a micro-macro model of its formation. Academy of Management Review, 28, 297-317.

LEV, B. 2000. Intangibles: Management, measurement, and reporting, Brookings Institution Press.

MARZO, G. \& SCARPINO, E. 2016. Exploring intellectual capital management in SMEs: an in-depth Italian case study. Journal of Intellectual Capital, 17, 27-51.

MERITUM, P. 2002. Guidelines for managing and reporting on intangibles. Fundación AirtelVodafone.

MOURITSEN, J. 2006. Problematising intellectual capital research: ostensive versus performative IC. Accounting, Auditing \& Accountability Journal, 19, 820-841.

MUSANTE, K. \& DEWALT, B. R. 2010. Participant observation: A guide for fieldworkers, Rowman Altamira.

NAHAPIET, J. \& GHOSHAL, S. 1998. Social capital, intellectual capital, and the organizational advantage. Academy of management review, 23, 242-266.

NELSON, R. R. \& WINTER, S. G. 1982. An Evolutionary Theory of Economic Change, Cambridge, Harvard University Press.

NONAKA, I. \& TAKEUCHI, H. 1995. The knowledge-creating company: How Japanese companies create the dynamics of innovation, London, Oxford university press.

NORTH, K. \& KARES, S. 2012. Ragusa or how to measure ignorance: The ignorance meter. Intellectual Capital for Communities, 348, 253-264.

NUNNALLY, J. C., BERNSTEIN, I. H. \& BERGE, J. M. T. 1967. Psychometric theory, JSTOR.

PATTON, M. Q. 2002. Qualitative Research and Evaluation Methods ( ${ }^{\text {rd }}$ Edition). Thousand Oaks, CA, Sage. 
PAYNE, A. F., STORBACKA, K. \& FROW, P. 2008. Managing the co-creation of value. Journal of the Academy of Marketing Science 36 (1):83-96.

PERECMAN, E. \& CURRAN, S. R. 2006. A Handbook for Social Science Field Research. Essays \& Bibliographic Sources on Research Design and Methods, Sage Publications.

SCHULTZ, T. W. 1961. Investment in human capital. The American economic review, 1-17.

SELEIM, A. \& BONTIS, N. 2013. National intellectual capital and economic performance: empirical evidence from developing countries. Knowledge and Process Management, 20, 131-140.

SGOUREV, S. V. 2013. How Paris gave rise to Cubism (and Picasso): Ambiguity and fragmentation in radical innovation. Organization Science, 24, 1601-1617.

SIEBER, R. \& WALKER, R. A. 1987. African art in the cycle of life, Washington, Smithsonian Books.

ST-PIERRE, J. \& AUDET, J. 2011. Intangible assets and performance: Analysis on manufacturing SMEs. Journal of Intellectual Capital, 12, 202-223.

SUBRAMANIAM, M. \& YOUNDT, M. A. 2005. The influence of intellectual capital on the types of innovative capabilities. Academy of Management journal, 48, 450-463.

TAVAKOL, M. \& DENNICK, R. 2011. Making sense of Cronbach's alpha. International journal of medical education, 2, 53.

TSAI, W. 2002. Social structure of "coopetition" within a multiunit organization: Coordination, competition, and intraorganizational knowledge sharing. Organization science, 13, 179-190.

VALE, J., BRANCO, M. C. \& RIBEIRO, J. 2016. Individual intellectual capital versus collective intellectual capital in a meta-organization. Journal of Intellectual Capital, 17, 279-297.

VERONA, G. 1999. A resource-based view of product development. Academy of management review, $24,132-142$.

WERNERFELT, B. 1984. A resource-based view of the firm. Strategic management journal, 5, 171180.

WILLIAMS, S. M. 2001. Is intellectual capital performance and disclosure practices related?. Journal of Intellectual capital, 2(3), 192-203.

WORLD BANK 2016a. Global Outlook: Disappointments, Risks, and Spillovers. Global Economic Prospects. Washington: World Bank.

WORLD BANK 2016b. Kenya Country Memorandum: From Economic Growhth to Jobs and Shared Prosperity. Washington: Wolrd Bank.

YIN, R. 1994. Case study research: Design and methods. Beverly Hills: CA: Sage publishing.

YOUNDT, M. A., SUBRAMANIAM, M. \& SNELL, S. A. 2004. Intellectual capital profiles: An examination of investments and returns. Journal of Management studies, 41, 335-361. 


\section{Acknowledgments}

The authors would like to thank the Artist for his valuable enthusiasm and continuous suggestions. We are also indebted to the cooperation of the respondents and especially to the assistance given by Susan who administered a great part of the data collection phase of this research directly in Kenya. We thank Graciela Carrasco and David Mark Kelly for providing excellent research assistance. The responsibility for the contents of this paper nonetheless remains entirely that of the authors. The helpful comments of the anonymous referee are also greatly acknowledged. 
Table 1 - Data sources

\begin{tabular}{|l|l|}
\hline Data sources (numbers in parentheses) & Details \\
\hline Questionnaires & 50 \\
\hline $\begin{array}{l}\text { Formal interviews (number of interviews performed): } \\
\text { - Artist/Project Founder (4) }\end{array}$ & 12 \\
- Empllaborator (2) & \\
- Restorer, Framer and Art-stealen (1) & \\
- Prt-Dealer (1) & \\
- Buyer (1) & \\
\hline $\begin{array}{l}\text { Informal interviews to the Artist/Project Founder, employees, collaborator, artists' friends, } \\
\text { etc. } \quad\end{array}$ & $>30$ \\
\hline $\begin{array}{l}\text { Observations in locu (laboratories, exhibitions, etc.) (days) } \\
\text { Documents collected (newspapers, projects, internal documents, multimedia, social } \\
\text { media, other) }\end{array}$ & \multirow{2}{*}{ Several } \\
- Press articles obtained from Factiva (46 press articles) & \\
- Websites & \\
- Photos (exhibitions, workplace, warehouses) & \\
- Sideo (2) & \\
\hline
\end{tabular}


Table 2 - Interviews

\begin{tabular}{|c|c|c|}
\hline Formal interviews & 12 & $\begin{array}{l}\text { Interview } \\
\text { Code }\end{array}$ \\
\hline Semi-structured & 8 & \\
\hline The Artist/Project Founder & 1 & INT1 \\
\hline The collaborator & 1 & INT2 \\
\hline The Restorer, Framer and Art-dealer & 1 & INT3 \\
\hline The Artist/Project Founder & 1 & INT4 \\
\hline Art-dealer & 1 & INT5 \\
\hline Photographer and former student of the Artist & 1 & INT6 \\
\hline The collaborator & 1 & INT7 \\
\hline Employee and former Art-student within the project & 1 & INT8 \\
\hline Structured & 4 & \\
\hline The Artist/Project Founder & 1 & INT9 \\
\hline Buyer & 1 & INT10 \\
\hline Employee and former Art-student within the project & 1 & INT11 \\
\hline The Artist/Project Founder & 1 & INT12 \\
\hline $\begin{array}{l}\text { Informal interviews to the Artist/Project Founder, Employee and former } \\
\text { Art-student within the project, collaborators, artists, friends, etc. }\end{array}$ & $>30$ & Not coded \\
\hline
\end{tabular}


Table 3 - Variables label, definition, measurement and function

\begin{tabular}{|c|c|c|c|}
\hline Label & Definition & $\begin{array}{l}\text { Measurement (refer } \\
\text { to table) }\end{array}$ & Function \\
\hline IC_Performance & $\begin{array}{l}\text { Output of intellectual capital in terms of } \\
\text { art creations, creativity and art training. }\end{array}$ & $\begin{array}{l}\text { Composite variable } \\
\text { deriving from the factor } \\
\text { analysis of three } \\
\text { questions (CREATIVE, } \\
\text { CREATE, ART_TR) }\end{array}$ & $\begin{array}{l}\text { Dependent } \\
\text { Variable }\end{array}$ \\
\hline HUMAN & $\begin{array}{l}\text { Knowledge, skills, and } \\
\text { abilities of the individuals (Schultz, } \\
\text { 1961). }\end{array}$ & $\begin{array}{l}\text { Composite variable } \\
\text { deriving from the factor } \\
\text { analysis of all the } \\
\text { questions except those } \\
\text { relating to the } \\
\text { respondents profile. }\end{array}$ & $\begin{array}{l}\text { Independent } \\
\text { Variable, } \\
\text { Test }\end{array}$ \\
\hline SOCIAL & $\begin{array}{l}\text { Knowledge integrated amongst } \\
\text { individuals and their relationships } \\
\text { developed through interactions, } \\
\text { networks, etc. (Nahapiet and Ghoshal, } \\
\text { 1998) }\end{array}$ & $\begin{array}{l}\text { Composite variable } \\
\text { deriving from the factor } \\
\text { analysis of all the } \\
\text { questions except those } \\
\text { relating to the } \\
\text { respondents profile. }\end{array}$ & $\begin{array}{l}\text { Independent } \\
\text { Variable, } \\
\text { Test }\end{array}$ \\
\hline $\begin{array}{l}\text { ORGANIZATI } \\
\text { ONAL }\end{array}$ & $\begin{array}{l}\text { The institutionalized knowledge and } \\
\text { codified experience } \\
\text { within and used by means of manuals, } \\
\text { structures, systems, databases, practices } \\
\text { and processes (Youndt et al., 2004). }\end{array}$ & $\begin{array}{l}\text { Composite variable } \\
\text { deriving from the factor } \\
\text { analysis of all the } \\
\text { questions except those } \\
\text { relating to the } \\
\text { respondents profile. }\end{array}$ & $\begin{array}{l}\text { Independent } \\
\text { Variable, } \\
\text { Test }\end{array}$ \\
\hline COMMUNITY & $\begin{array}{l}\text { Community values, spirit and principles } \\
\text { apt to bond human capital with different } \\
\text { resources generating cohesion } \\
\text { (Edvinsson, 2005; North and Kares, } \\
\text { 2005). }\end{array}$ & $\begin{array}{l}\text { Composite variable } \\
\text { deriving from the factor } \\
\text { analysis of all the } \\
\text { questions except those } \\
\text { relating to the } \\
\text { respondents profile. }\end{array}$ & $\begin{array}{l}\text { Independent } \\
\text { Variable, } \\
\text { Test }\end{array}$ \\
\hline $\begin{array}{l}\text { COMMUNITY } \\
\text { *SOCIAL }\end{array}$ & $\begin{array}{l}\text { Community moderating effect on the } \\
\text { social resources. }\end{array}$ & $\begin{array}{l}\text { Interaction term } \\
\text { between } \\
\text { COMMUNITY and } \\
\text { SOCIAL. }\end{array}$ & $\begin{array}{l}\text { Independent } \\
\text { Variable, } \\
\text { Test }\end{array}$ \\
\hline $\begin{array}{l}\text { COMMUNITY } \\
\text { *ORGANIZAT } \\
\text { IONAL }\end{array}$ & $\begin{array}{l}\text { Community moderating effect on the } \\
\text { organizational resources. }\end{array}$ & $\begin{array}{l}\text { Interaction term } \\
\text { between } \\
\text { COMMUNITY and } \\
\text { ORGANIZATIONAL. }\end{array}$ & $\begin{array}{l}\text { Independent } \\
\text { Variable, } \\
\text { Test }\end{array}$ \\
\hline AGE & Respondents' age. & $\begin{array}{l}\text { Continuous variable, } \\
\text { age of the respondents. }\end{array}$ & $\begin{array}{l}\text { Control } \\
\text { Variable }\end{array}$ \\
\hline
\end{tabular}




\begin{tabular}{|l|l|l|l|}
\hline SEX & Respondents' sex. & $\begin{array}{l}\text { Dummy, 0 if the } \\
\text { respondent is male, 1 } \\
\text { otherwise. }\end{array}$ & $\begin{array}{l}\text { Control } \\
\text { Variable }\end{array}$ \\
\hline EDUCATION & $\begin{array}{l}\text { It summarises the level of education } \\
\text { attained and the field of education. }\end{array}$ & $\begin{array}{l}\text { Composite variable } \\
\text { deriving from the factor } \\
\text { analysis (EDU_L and } \\
\text { EDU_F). }\end{array}$ & $\begin{array}{l}\text { Control } \\
\text { Variable }\end{array}$ \\
\hline ARTTYPE & $\begin{array}{l}\text { The type of arts or cultural activities } \\
\text { performed by respondents. }\end{array}$ & $\begin{array}{l}\text { Categorical variable } \\
\text { from 1 to 12, according } \\
\text { to diverse art and } \\
\text { cultural activities. }\end{array}$ & $\begin{array}{l}\text { Control } \\
\text { Variable }\end{array}$ \\
\hline GROUP & $\begin{array}{l}\text { Population group in which respondents } \\
\text { classify (i.e. Black African; Coloured; } \\
\text { Indian or Asian; } \text { White; } \text { Other). }\end{array}$ & $\begin{array}{l}\text { Categorical variable } \\
\text { from 1 to 5. }\end{array}$ & $\begin{array}{l}\text { Control } \\
\text { Variable }\end{array}$ \\
\hline
\end{tabular}


Table 4 - IC performance, organization's resources and community aspects

\begin{tabular}{|c|c|c|c|}
\hline VARIABLES & $\begin{array}{c}(1) \\
\text { IC_Performance }\end{array}$ & $\begin{array}{c}\text { (2) } \\
\text { IC_Performance }\end{array}$ & $\begin{array}{c}(3) \\
\text { IC_Performance }\end{array}$ \\
\hline HUMAN & $\begin{array}{c}\mathbf{0 . 1 9 2 * * *} \\
(0.032)\end{array}$ & $\begin{array}{l}\mathbf{0 . 2 4 8 * * *} \\
(0.036)\end{array}$ & $\begin{array}{c}\mathbf{0 . 2 4 6} * * * \\
(0.042)\end{array}$ \\
\hline SOCIAL & $\begin{array}{c}\mathbf{0 . 4 5 5 * * *} \\
(0.037)\end{array}$ & $\begin{array}{c}\mathbf{0 . 3 8 7} * * * \\
(0.047)\end{array}$ & $\begin{array}{c}\mathbf{0 . 4 1 3 * * *} \\
(0.058)\end{array}$ \\
\hline ORGANIZATIONAL & $\begin{array}{c}\mathbf{0 . 3 7 6} * * * \\
(0.020)\end{array}$ & $\begin{array}{c}\mathbf{0 . 3 5 3} * * * \\
(0.028)\end{array}$ & $\begin{array}{c}\mathbf{0 . 3 4 7} * * * \\
(0.027)\end{array}$ \\
\hline COMMUNITY & & & $\begin{array}{c}0.021 \\
(0.071)\end{array}$ \\
\hline SOCIAL *COMMUNITY & & & $\begin{array}{l}\mathbf{0 . 0 9 9 *} \\
(0.058)\end{array}$ \\
\hline ORGANIZATIONAL*COMMUNITY & & & $\begin{array}{l}\mathbf{- 0 . 0 1 6} \\
(0.059)\end{array}$ \\
\hline AGE & & $\begin{array}{c}0.002 \\
(0.006)\end{array}$ & $\begin{array}{c}0.000 \\
(0.006)\end{array}$ \\
\hline SEX & & $\begin{array}{r}0.287^{* *} \\
(0.123)\end{array}$ & $\begin{array}{l}0.273^{* *} \\
(0.110)\end{array}$ \\
\hline EDU & & $\begin{array}{c}0.454 \\
(0.324)\end{array}$ & $\begin{array}{l}0.570 \\
(0.342)\end{array}$ \\
\hline ART_TYPE & & $\begin{array}{l}0.030^{*} \\
(0.015)\end{array}$ & $\begin{array}{l}0.032 * \\
(0.017)\end{array}$ \\
\hline POP_GROUP & & $\begin{array}{c}0.051 \\
(0.036)\end{array}$ & $\begin{array}{c}0.032 \\
(0.046)\end{array}$ \\
\hline Constant & $\begin{array}{c}0.036 \\
(0.047)\end{array}$ & $\begin{array}{l}-0.592 * \\
(0.321)\end{array}$ & $\begin{array}{l}-0.514 \\
(0.343)\end{array}$ \\
\hline Observations & 50 & 50 & 50 \\
\hline R-squared & 0.790 & 0.835 & 0.854 \\
\hline Prob $>F$ & 0.000 & 0.000 & 0.000 \\
\hline $\begin{array}{l}\text { Robust standard errors in parentheses } \\
\text { Significance levels } * * * p<0.01, * * p<0.05 \text {, }\end{array}$ & 1 & & \\
\hline
\end{tabular}


Appendix 1 - Survey questionnaire

\begin{tabular}{|c|c|}
\hline Questions & Label \\
\hline \multicolumn{2}{|l|}{ Section 1: Respondents' profile } \\
\hline Age & AGE \\
\hline Sex $[1-2 ; 1:$ male; $2:$ female $]$ & SEX \\
\hline $\begin{array}{l}\text { My level of education attained [1-5; } 1 \text { : No schooling; } 2 \text { : elementary schools; } 3 \text { : } \\
\text { professional school; 4: high school; 5: university]. }\end{array}$ & EDU_L \\
\hline $\begin{array}{l}\text { My field of education [if any] [1-18; 1: Agriculture; 2: Architecture or } \\
\text { Environments Design; 3: Arts, Visual or Performing; 4: Business, Commerce or } \\
\text { Management Sciences; 5: Communication; 6: Computer Sciences; 7: Education, } \\
\text { Training or Development; 8: Engineering; 9: Health Care; 10: Home Economics; } \\
\text { 11: Language; 12: Law; 13: Mathematical Sciences; 14: Philosophy, Religion or } \\
\text { Theology; 15: Physical education or Leisure; 16: Psychology; 17: Public } \\
\text { Administration or Social Services; 18: Other] }\end{array}$ & EDU_F \\
\hline My years of professional experience $[a-c ; a:<1$ year; $b: 1-5$ years; $c:>5$ years]. & EXP \\
\hline $\begin{array}{l}\text { Describe yourself in terms of population group }[1-5 ; 1: \text { Black Africa; } 2 \text { : Coloured; } \\
\text { 3: Indian or Asian; 4: White; } 5: \text { Other }] \text {. }\end{array}$ & POP_GROUP \\
\hline \multicolumn{2}{|l|}{ Section 2: Creativity issues } \\
\hline $\begin{array}{l}\text { The type(s) of arts and cultural activities I perform are [up to } 3 \text { choices] [1-; 1: } \\
\text { Architecture; 2: Crafts; 3: Dance; 4: Design Arts; 5: Media Arts (film, audio, } \\
\text { video); 6: Music; 7: New Media (e.g. computer graphics); 8: Painting/Drawing; } \\
\text { 9: Photography; 10: Sculpture; 11: Theatre/Cinema; 12: Other] }\end{array}$ & ART_TYPE \\
\hline I am creative $[1-5 ; 1$ : strongly disagree; 5 : strongly agree $]$ & CREATIVE \\
\hline $\begin{array}{l}\text { I try to create something }[1-4 ; 1: \text { every day; } 2: \text { several times a week; } 3: \text { several } \\
\text { times a month; } 4 \text { : never }]\end{array}$ & CREATE \\
\hline $\begin{array}{l}\text { I have noticed an evolution/change in my creativity since I start working with the } \\
\text { Artist/Project Founder [1-5; 1: strongly disagree; 5: strongly agree] }\end{array}$ & ART_TR \\
\hline $\begin{array}{l}\text { Creativity is a skill that can be applied to every domain of knowledge }[1-5 ; 1 \text { : } \\
\text { strongly disagree; } 5: \text { strongly agree }]\end{array}$ & C_KNOW \\
\hline $\begin{array}{l}\text { Creativity is only relevant to visual arts, music, drama and artistic performance [1- } \\
\text { 5; 1: strongly disagree; 5: strongly agree }]\end{array}$ & C_FIELD \\
\hline $\begin{array}{l}\text { Creativity is a characteristic of eminent people only }[1-5 ; 1: \text { strongly disagree; } 5 \text { : } \\
\text { strongly agree }]\end{array}$ & C_EMINENT \\
\hline Creativity is an inborn talent [1-5; 1: strongly disagree; 5 : strongly agree $]$ & C_INBORN \\
\hline $\begin{array}{l}\text { Creativity varies according to age groups [1-5; 1: strongly disagree; } 5 \text { : strongly } \\
\text { agree }]\end{array}$ & C_AGE \\
\hline $\begin{array}{l}\text { Creativity is the ability to produce something original }[1-5 ; 1 \text { : strongly disagree; } \\
\text { 5: strongly agree }]\end{array}$ & C_ORIGINAL \\
\hline $\begin{array}{l}\text { Creativity is about finding connections between things that have not been } \\
\text { connected before }[1-5 ; 1: \text { strongly disagree; } 5: \text { strongly agree }]\end{array}$ & C_CONN \\
\hline $\begin{array}{l}\text { Creativity is the ability to produce something of value }[1-5 ; 1 \text { : strongly disagree; } \\
\text { 5: strongly agree }]\end{array}$ & C_VALUE \\
\hline Creativity can be taught $[1-5 ; 1$ : strongly disagree; 5 : strongly agree $]$ & C_TAUGHT \\
\hline Creativity can be assessed [1-5; 1 : strongly disagree; 5 : strongly agree] & C_ASS \\
\hline $\begin{array}{l}\text { Creativity is a fundamental skill to be developed in school [1-5; 1: strongly } \\
\text { disagree; 5: strongly agree] }\end{array}$ & C_SCHOOL \\
\hline \multicolumn{2}{|l|}{ Section 3: Organizational issues } \\
\hline My Role within the organization is $[1-4 ; 1:$ staff; 2 : employee; 3 : student; 4 : & ROLE \\
\hline
\end{tabular}




\begin{tabular}{|c|c|}
\hline other] & \\
\hline $\begin{array}{l}\text { I have worked/studied in this organization for }[a-d ; a:<1 \text { year; } b: 1-2 \text { years; } c \text { : } \\
3-5 \text { years; } d:>5 \text { years }]\end{array}$ & TENURE \\
\hline $\begin{array}{l}\text { Per day I normally work in this organization }[a-c ; a:<6 \text { hours; } b: 6-9 \text { hours; } c:> \\
9 \text { hours }]\end{array}$ & HOUR \\
\hline $\begin{array}{l}\text { Per week I normally work in this organization [a: 1-3 days per week; } b: 4-5 \text { days; } \\
c:>5 \text { days }]\end{array}$ & DAYS \\
\hline My work is performed $[1-3 ; 1:$ indoor; $2:$ outdoor; $3:$ both $]$ & IN_OUT \\
\hline $\begin{array}{l}\text { What did you do before joining this organization [1: student; } 2: \text { worker not related } \\
\text { to art; 3: work related to art; 4: unemployed] }\end{array}$ & $\begin{array}{l}\text { PRIOR_WOR } \\
\text { K }\end{array}$ \\
\hline I use to report to [1-3; $1:$ art director; 2 : head of the organization; $3:$ nobody $]$ & REPORT \\
\hline I interact with my co-workers $[1-3 ; 1:$ informally; 2 : formal meetings; $3:$ mails $]$ & INTERACT \\
\hline $\begin{array}{l}\text { I am encouraged by my colleagues in pursuing my work [1-5; 1: strongly } \\
\text { disagree; 5: strongly agree }]\end{array}$ & ENC \\
\hline Section 4: Cultural/artistic issues & \\
\hline $\begin{array}{l}\text { My primary motivation when it comes to working is }[1-5 ; 1: \text { money; } 2: \text { personal } \\
\text { goals; } 3 \text { : helping the community \&/or the territory; } 4: \text { competition; } 5: \text { other }]\end{array}$ & $\begin{array}{l}\text { MOTIVATIO } \\
\mathrm{N}\end{array}$ \\
\hline $\begin{array}{l}\text { The advantage(s) of being part of this organization is (are) [up to } 2 \text { choices] [1-4; } \\
\text { 1:Possibility of education/training; } 2: \text { Higher chances of having a broader } \\
\text { audience; 3: Higher future employability; } 4: \text { Being part of an artistic movement } \\
\text { employability] }\end{array}$ & ADV \\
\hline $\begin{array}{l}\text { The disadvantage(s) of being part of this organization is (are) [up to } 2 \text { choices] [1- } \\
\text { 3; 1:Distance from the family and/or hometown; } 2: \text { Risk of being copied; } 3: \\
\text { Presence of constraints in the creativity process; } 4: \text { no disadvantages }]\end{array}$ & DISADV \\
\hline $\begin{array}{l}\text { My cultural background affects my current work [1-5; 1: strongly disagree; } 5 \text { : } \\
\text { strongly agree }]\end{array}$ & CULT_BACK \\
\hline $\begin{array}{l}\text { Section 5: Knowledge sharing process } \\
\end{array}$ & \\
\hline $\begin{array}{l}\text { The working environment supports knowledge sharing [Scale 1-5; 1: strongly } \\
\text { disagree; 5: strongly agree }]\end{array}$ & ENV \\
\hline $\begin{array}{l}\text { Who is more willing to share information? [1-3; } 1: \text { juniors; } 2 \text { : experienced } \\
\text { workers; } 3 \text { : no difference] }\end{array}$ & INFO_SHARE \\
\hline $\begin{array}{l}\text { The tools and spaces available in my working environment facilitate the transfer of } \\
\text { information among workers }[1-5 ; 1: \text { strongly disagree; } 5 \text { : strongly agree }]\end{array}$ & $\begin{array}{l}\text { TOOLS_SPA } \\
\text { CE }\end{array}$ \\
\hline Section 6: Community aspects & \\
\hline $\begin{array}{l}\text { I feel part of the community in which I work [1-5; 1: strongly disagree; } 5 \text { : } \\
\text { strongly agree }]\end{array}$ & COMM \\
\hline I feel judged by my colleagues for the work I perform $[1-5 ; 1$ : always; 5 : never $]$ & JUDGE \\
\hline I know well my colleagues $[1-5 ; 1:$ not at all; $5:$ really well] & COLL \\
\hline I am afraid that someone could steal my ideas [1-5; 1: not at all; 5 : strongly] & IDEA \\
\hline $\begin{array}{l}\text { Section 7: Personal thoughts of knowledge sharing } \\
\end{array}$ & 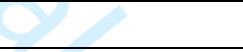 \\
\hline $\begin{array}{l}\text { I share pieces of information concerning my work with my colleagues }[1-4 ; 1 \text { : } \\
\text { always; } 2 \text { : sometimes; } 3: \text { rarely; } 4: \text { never }]\end{array}$ & $\begin{array}{l}\text { INFO_SHARE } \\
2\end{array}$ \\
\hline I usually perform my work [1-3; 1: in-group; 2 : alone; $3:$ both $]$ & $\begin{array}{l}\text { INGROUP_A } \\
\text { LONE }\end{array}$ \\
\hline $\begin{array}{l}\text { I am willing to listen when people of my organization talk about things I don't like } \\
\text { or believe in }[1-5 ; 1 \text { : not at all; } 5 \text { : completely }]\end{array}$ & LISTEN \\
\hline $\begin{array}{l}\text { When faced with a problem, I am most likely to }[1-4 ; 1: \text { Use a solution that } \\
\text { worked in the past; } 2 \text { : ask a colleague for help; } 3: \text { try and think up a new solution; } \\
\text { 4: work on several possible solutions]. }\end{array}$ & PROBL \\
\hline
\end{tabular}


I often organize (or write down) my ideas/projects [1-5; 1: strongly disagree; 5 : $\quad$ PROJ_ORG strongly agree]

\begin{tabular}{l|l}
\hline I tend to follow a routine at work [1-5; 1: strongly disagree; 5 : strongly agree $]$ & ROUTINE
\end{tabular}

\begin{tabular}{l|l}
\hline I like working with other people $[1-5 ; 1$ : not at all; 5 : really well $]$ & WORK_OT_P
\end{tabular}

EOPLE 


\section{Appendix 2 - General interview guide}

1. Do you know the "The Artist/Project Founder" (hereafter A/PF)?

2. Do you consider him as an Artist?

3. How did the A/PF initiate with Art?

4. Would you categorise the $\mathrm{A} / \mathrm{PF}$ in a category of art? Painter, sculptor or what else?

5. Do you find some peculiar traits that distinguish the A/PF from other artists of the same period? (E.g. Enthusiasm, love for the African traditions, use of multiple art techniques, other).

6. Where does the $\mathrm{A} / \mathrm{PF}$ take inspiration?

7. What kind of Art education and training did the A/PF had?

8. Which influence did the family had on the $\mathrm{A} / \mathrm{PF}$ expression?

9. Which is the relation between a contemporaneous artist, as the $\mathrm{A} / \mathrm{PF}$, and other artists of the past?

10. How did you get to know the works of the A/PF?

11. What do you most appreciate of the A/PF's art works?

12. Why do you buy the A/PF's works? (E.g. investment, I like them, both, etc.).

13. Have you ever bought and resell the A/PF's artwork?

14. Do you know the A/PF's love for Africa?

15. Why did the A/PF choose Kenya?

16. Do African artists share their knowledge?

17. Are there, according to you, some peculiarities in the process of knowledge sharing and in the process of art creation in Kenya?

18. Can you describe how do the activities are carried out in the A/PFs' laboratories and spaces in Kenya?

19. Which peculiarities do you find in the A/PF's organization and in his human resources management?

20. How is the intellectual capital/art creation valorised?

21. Do you think that the A/PF's work benefits from the African traditions?

22. How do you think Kenya contributes to the work of the A/PF? And/Or viceversa?

23. Which are according to you the values, messages and ideals that the A/PF spreads through his works?

24. Do you know the "White Elephant Project"?

25. Have you ever heard about the A/PF's desire to create a School of Art in Kenya?

26. Do you think that Kenya might benefit from the above desire? If yes, in which sense? What type of benefits?

27. Which is the relation between the $\mathrm{A} / \mathrm{PF}$ and African artists?

28. Do you know how the work is organized at the A/PF's School of art (organization) in Kenya? If yes, could you please describe it to us.

29. What are the main differences between the A/PF's art creations and the other artists' creations you buy?

Questions were adapted according to the interviewee. 